\title{
TAX EXHAUSTION, FIRM INVESTMENT, AND LEASING: \\ A TEST OF THE Q MODEL OF INVESTMENT
}

\author{
MiChAEL P. O'MALLEY ${ }^{* *}$ \\ BoARD OF Governors of the FEDERAL RESERVE System
}

Michael P. O'Malley; Board of Governors of the Federal Reserve System; $20^{\text {th }}$ and C Streets; Stop 92; Washington, DC 20551. (202) 452-3325. m1mpo00@frb.gov.

James M. Poterba, Jonathan H. Gruber, and Andrew W. Alford provided guidance and advice. Yolanda K. Kodrzycki provided data and programming assistance. 


\section{Introduction}

Interfirm variation in taxation is a notable feature of virtually all corporation tax codes. Different tax codes have different provisions that generate this variation, but the asymmetric treatment of taxable losses and gains is common. Firms with positive taxable incomes pay taxes, whereas "tax-loss" firms (i.e., firms with negative taxable income) do not receive refunds and must carry these taxable losses either back or forward to other periods when the firm would have positive income after subtracting the losses. In the former case, the firm receives a refund of taxes previously paid, but in the latter, carryforward case, the "tax-loss carryforward" is claimed eventually, if ever, at its nominal value. As a result, the present value of the deductions that brought the firm into tax-loss status is reduced. Depreciation deductions associated with investment are the most significant for moving firms into tax-loss status. If such deductions must be carried forward due to tax exhaustion, then incentives to invest are reduced.

Ample evidence suggests that this asymmetry is important. For example, Cordes and Sheffrin (1983) report that only 56 percent of corporate receipts accrued to firms that paid the maximum statutory corporate tax rate on marginal earnings. The need to incorporate tax factors into investment models has been promulgated through the Hall-Jorgenson cost-of-capital model, and if investors efficiently incorporate all information, including a firm's tax status, into stock prices, then tax effects should be incorporated into $Q$ models of investment. Nevertheless, few papers on investment consider tax asymmetries because firm-level data with the relevant parameters are difficult to get. Easily obtained aggregate data are not useful, because the firm-level tax nonlinearities are obscured by aggregation. Devereux, Keen, and Schiantarelli (1994) estimate both cost-of-capital and Q investment equations that take account of not only the tax-loss asymmetry but also the asymmetry associated with the Advance Corporation Tax (ACT) that is part of the British corporation tax. Although the data include considerable cross-sectional 
and intertemporal tax variation, the conclusion is that "specifications that capture the full complexities of corporate taxation perform no better than ones which ignore it altogether," as the results of both specifications are essentially invariant to controls for the tax asymmetries.

Two possible conclusions emerge: first, measurement and/or specification problems remain; and second, arbitrage devices (particularly leasing) could equilibrate the interfirm tax treatment differentials so that there is no overall tax effect on investment. Indeed, leasing has become quite popular during the past decade; whereas about 18 percent of equipment was leased in 1984, 34 percent was leased in 1989, and approximately 32 percent was leased in 1991 and $1992{ }^{1}$ However, rigorous analysis of tax-motivated leasing has proved difficult because data on leasing are difficult to use, as financial reporting methodologies create data that are not immediately comparable with data on investment financed by other means. Nevertheless, adjusting for leasing not only addresses its role as a way to arbitrage away cost of capital differences but also because the primary principle of leasing is that returns come from using equipment, not merely owning it, and investment theory generally implies an explanation of use.

This paper addresses two concerns: first, the effect of tax exhaustion on investment, including possible effects of leasing; and second, by properly accounting for tax losses and leasing, it is hoped that a better specification of investment will obtain and improve the performance of the $Q$ model of investment. The theoretical appeal of $Q$ for explaining investment reflects that $Q$ equals the net shadow value of investment for maximizing a firm's equity value. If the firm operates from the equityholder's point of view, then standard marginal productivity conditions yield that investment is a positive function of $Q$. However, the empirical performance of $Q$ has not matched expectations. In many papers, $Q$ coefficients

$1 \quad$ See Equipment Leasing Association (1992). 
seem small, while other variables that have no theoretical grounding in a $Q$ framework (most notably cash flow) are not only significant but seem quite large. Given usual parameterizations of the adjustment cost function, the small estimates of the $Q$ coefficient imply adjustment costs that seem implausibly high. The interest in investment is obvious, but the concern with high adjustment cost functions are of particular interest to policy makers, because they imply that extremely generous tax incentives are needed to overcome the high adjustment costs and increase investment. It seems useful to correct possible measurement error and/or misspecification before rejecting $Q$ for explaining investment or despairing that adjustment costs render investment tax incentives prohibitively expensive.

This paper first derives $Q$ measures that reflect both tax exhaustion and leasing. Investment equations are estimated, and the results confirm that $Q$ specifications are especially improved by controlling for leasing: the $Q$ coefficients do increase, implying lower, more plausible adjustment costs and that measurement error may affect the previous $Q$ coefficients that seem too low. Nevertheless, unresolved problems for $Q$ are demonstrated. First, although theory suggests a powerful effect of tax exhaustion on affected firms' investment decisions, and empirical work has shown the effects of these tax factors on costs of capital and effective tax rates (for example, see Auerbach (1986), Auerbach and Poterba (1987), Edwards and Keen (1985), and Mayer (1986)), when careful treatment of tax asymmetries are included in tax-adjusted $Q$ measures, sufficient variation does not obtain between the measures to affect significantly the coefficient estimates. A conclusion, as in Devereux, Keen, and Schiantarelli (1994), is that the result may confirm leasing's equilibrating effect on firms' differential costs of capital. However, when tax-loss carryforwards (scaled by sales) are entered into $Q$ equations both with and without leasing, the coefficients are large, negative, and significant. Moreover, when carryforwards are interacted with $Q$, the coefficient of the interaction term is significantly negative; i.e., the effect of $Q$ for explaining 
investment is lower for tax-loss firms. This finding helps to explain why earlier results for $Q$ have seemed low -- without controlling for tax exhaustion, $Q$ coefficients confound the effect of $Q$ and tax exhaustion. Overall therefore, while tax exhaustion does appear to have significant effects on investment so that $Q$ results should be significantly affected when controlling for tax exhaustion, the insensitivity of $Q$ to tax exhaustion remains an unresolved problem.

Five sections compose the paper. The first section describes the tax-adjusted $Q$ model. Section 2 provides a basic overview of tax exhaustion and leasing that motivates the need to control explicitly for both when modelling investment with $\mathrm{Q}$. The third section presents the testing strategies and how they may be introduced into the $Q$ model as well as discussions on data handling and econometrics. Section 4 contains results, and section 5 concludes.

\section{$1 \quad$ Modelling Investment with Tax-adjusted Q}

Rather than repeating the rigorous derivations of the $Q$ model provided in numerous other places (for example, see Tobin (1969), Hayashi (1982), Summers (1981), and Poterba and Summers (1983)), I provide the intuition for $Q$ and concentrate on how to incorporate taxes and leasing into the $Q$ variable itself. Tobin (1969) develops the intuition for the tax-adjusted $Q$ model used here. "Tobin's q" is the shadow value of capital for maximizing firms' equity values. For firms that operate from the equityholder's point of view, standard marginal productivity conditions yield that investment should continue until marginal investment raises the value of equity by q; therefore, investment is a positive function of q. To make the rate of investment determinate, adjustment and installation costs are introduced to prevent instantaneous adjustment to the optimal capital stock. First-order conditions state that the marginal adjustment costs of investment equal q, which explains why low coefficients imply high adjustment costs. Given a parameterization of adjustment costs and assuming that marginal 
valuations of capital (relative to replacement costs) equal average valuations, the following technological relation between the optimal level of investment (I) and $q$ obtains:

$$
\begin{gathered}
\frac{l}{K}=i\left(\frac{V}{K}\right)=i(q) \\
\mathrm{i}(1)=0, \mathrm{i}^{\prime}>0
\end{gathered}
$$

where $\mathrm{V}$ equals the market valuation of the firm and $\mathrm{K}$ equals the replacement value of its capital stock.

Summers (1981) augments Tobin's q to obtain a tax-adjusted q parameter, denoted $Q$. The first change reflects financing considerations. If $b$ equals the fraction of new investment financed with debt, then the above relation is modified first to be:

$$
\begin{gathered}
\frac{l}{K}=h\left(\frac{V-N}{K}-(1-b)\right) \\
h(0)=0, h^{\prime}>0
\end{gathered}
$$

where $h(\cdot)$ links investment and adjustment costs. From an equityholder's point of view, a firm should invest until the increase in equity value equals its cost, which equals (1-b) after normalizing the price of investment goods. Because $Q$ most commonly explains equipment investment, inventories $(N)$ are subtracted from firms' market values and not reflected in the replacement value term.

Taxes affect both the gain from and the cost of investing. In the $Q$ framework, taxes payable on the gains from investment are incorporated into the market valuation. Tax investment allowances reduce the cost of investment from the equityholder's view and are therefore reflected in the construction of $Q$ : 


$$
\frac{I}{K}=h\left(\frac{V-B-N}{K}-(1-b-I T C-Z)\right)
$$

$$
\mathrm{h}(0)=0, \mathrm{~h}^{\prime}>0
$$

where ITC and $Z$ represent the values of an investment tax credit and the present value of depreciation deductions on $\$ 1$ of investment. Because $Q$ is to capture valuations of new equipment (again relative to replacement costs), the capitalized value of depreciation deductions that stem from existing capital, $B$, is subtracted from the firm's market valuation.

The individual tax treatment of equityholders and the favorable tax treatment of capital gains relative to dividends suggest that firms would invest beyond where market values increase by $\$ 1$. They invest until market values increase by $\Theta$, the ratio of the after tax return from $\$ 1$ in dividends to $\$ 1$ in capital gains; i.e.,

$$
\begin{gathered}
\frac{l}{K}=h\left(\frac{V-B-N}{K} \Theta-(1-b-I T C-Z)\right) . \\
h(0)=0, h^{\prime}>0
\end{gathered}
$$

A final modification recognizes the tax-deductibility of adjustment costs. Firms invest until the market value of the additional capital minus its acquisition cost equals the after-tax cost of installation:

$$
\begin{gathered}
\frac{I}{K}=h\left(\frac{\frac{V-B-N}{K} \Theta-(1-b-I T C-Z)}{(1-\tau)}\right)=h(Q) . \\
h(0)=0, h^{\prime}>0
\end{gathered}
$$

Equation (1) is the standard $Q$ model of investment. Given its derivation and the standard parameterizations of adjustment costs, $Q$ is a sufficient statistic for 
investment incentives; therefore, it alone serves as a regressor in equations explaining the rate of investment.

\section{Tax Exhaustion and Leasing}

The $Q$ model assumes that the marginal gain from investment is equal, optimally, to its marginal cost. The nonlinearity of the corporate income tax at the taxable income of zero affects the timing and hence the present value of any tax accrual resulting from marginal investment. For example, if a nontaxable firm invests and cannot carry back its negative taxable income to offset previous periods' positive taxable income, then it must wait to claim any deductions, including those that result from investment, until it is again taxable. This scenario reduces the present value of such capital cost recovery allowances and therefore increases the cost of investment. On the other hand, a surplus of deductions shelters taxable income, reducing taxes payable on gains from investment and therefore increasing net gains. The first scenario reduces incentives to invest, while the latter increases such incentives; obviously, the timing and duration of spells of tax disadvantage determine the overall effect.

Nevertheless, these cost disadvantages are really cost of ownership disadvantages; that is, an implicit assumption is that firms purchase their investment goods, rather than lease them. As O'Malley (1994a) shows, cost of ownership differentials caused by interfirm variation in taxation create incentives for leasing. If a tax disadvantaged firm substitutes into leasing instead of purchasing equipment, so that its net capital stock in use remains at an optimal level (i.e., total investment of both purchased and leased assets does not change), then the deleterious effects of tax disadvantage on the cost of capital are undone.

This situation has three primary implications for modelling Q. First, the investment incentives implicit in the construction of $Q$ must reflect the effects of tax 
exhaustion. Second, inclusion of leasing into the $Q$ framework is necessary and, in fact, entirely consistent with its theoretical underpinnings. In the development of q, a firm's market value is shown to equal the present value of dividends that a firm's capital facilitates. Because leased equipment also generates income that can be returned to investors as dividends, a firm's market value must also reflect returns from its leased capital stock; therefore, the replacement value term in $Q$ should also reflect leased assets. Third, because tax exhausted firms have incentives to invest through leasing, which may ameliorate the deleterious investment incentives of tax exhaustion, $Q$ must reflect tax benefits received indirectly through lower lease payments. If the lease market is competitive, such that ITC and $Z$ are passed to the lessee by relatively low lease payments, then the ITC and $Z$ terms in a lessee's $Q$ should equal what its tax advantaged lessor receives.

Further, the fact that leasing is thought to have an economic content similar to debt is relevant because of the adjustment in $Q$ for the share of assets that is financed with debt, $b$. Because $Q$ represents the shadow value of investment for maximizing the value of equity, payments to debtholders -- including lessors -must be netted out of the equation.

\section{$3 \quad$ Testing Strategies, Data Handling, and Econometrics}

Six specifications of $Q$ are devised that increase progressively the recognition of tax exhaustion and leasing. The first ignores both tax exhaustion and leasing. The second accounts for tax exhaustion in a fairly crude way, while the third employs a more elaborate method to control for tax exhaustion. The fourth, fifth, and sixth specifications reflect total investment -- both owned and leased -- but are otherwise analogous to specifications one, two, and three with respect to how they control for a firm's tax status. 


\section{1.a Q Specifications}

"Normal Q" serves as the benchmark case. This version is the traditional taxadjusted $Q$ model of investment that ignores both tax-asymmetries and leasing; therefore, investment and capital stock data reflect only owned assets, and all tax terms are entered at their statutory values.

$$
\text { normal } Q=\frac{\frac{V-B-N}{K} \Theta-(1-b-I T C-Z)}{(1-\tau)}
$$

While normal $Q$ assumes implicitly that every firm is taxable, $Q$-plus reflects the possibility that some firms are nontaxable. In Q-plus, the tax terms for tax-loss firms equal zero (denoted by ${ }^{*}$ ), suggesting that these terms have no value to affected firms and therefore assuming that these firms never transit back into taxable status when they would claim their deductions.

$$
\text { Q-plus }=\frac{\frac{V-B^{*}-N}{K} \Theta-\left(1-b-I T C^{*}-Z^{*}\right)}{\left(1-\tau^{*}\right)}
$$

Super Q-plus refines further the adjustments for tax exhaustion. The tax exhaustion adjustments in Q-plus likely exaggerate the effects of tax exhaustion because of the assumption that tax-loss firms never transit back into taxable status to claim their tax-loss carryforwards. Although Auerbach and Poterba (1987) find considerable persistence in firms' tax statuses, there remain nontrivial probabilities that nontaxable firms transit back into taxable status and for currently taxable firms to at some point become nontaxable. ${ }^{2}$ Parameterizing the transitions between taxable and tax-loss status is difficult, because of uncertainty about a firm's future tax status. However, the assumption that realized values of second-order Markov transition probabilities between tax statuses are appropriate for predicting similar 
future transitions makes possible a probabilistic distribution of dates when current and future tax benefits and payments may be realized. By discounting across these possible dates of realization, the expected present values of tax terms is found, and these expressions can enter the specifications of $Q .{ }^{3}$

$$
\text { super } Q \text {-plus }=\frac{\frac{V-B^{* *}-N-T L C F^{* *}}{K} \Theta-\left(1-b-I T C^{* *}-Z^{* *}\right)}{\left(1-\tau^{* *}\right)}
$$

Because tax-loss carryforwards (TLCF) may be claimed and reduce taxes at some future date, they represent a financial asset that is assumably priced into equity values. For the same reasons that inventories and future depreciation deductions for existing capital are subtracted to compute $Q, T L C F$ is also netted out of $Q .{ }^{4}$

Normal $Q_{1}$ reflects a firm's leasing activity (if any) but is otherwise analogous to normal $Q$ because it ignores the possibility of tax exhaustion. The leasing adjustments are determined by the assumption that leases are equivalent to a purchase with debt; therefore, the leased shares of investment and the capital stock are equivalent in use to the owned components, so that total capital in use -both owned and leased -- is used on both the left- and right-hand sides of the equation as appropriate. The $b$ term, which reflects the share of capital acquired with debt, is also adjusted to reflect lease debt in the numerator and leased capital in the denominator. Under the assumption that the lease market is efficient so that lower lease payments pass tax investment incentives to the lessee, the ITC and $Z$ terms are the values that would be received by a tax advantaged lessor. Terms that are affected by leasing are denoted by ${ }^{+}$.

$3 \quad$ More detailed explanations of this technique appear in Auerbach and Poterba (1987), Altshuler and Auerbach (1987), and O'Malley (1994b).

$4 \quad$ This term does not appear in Q-plus because, under the assumption that tax-loss firms are never again taxable, it has no value. 


$$
\text { normal } Q_{1}=\frac{\frac{V-B-N}{K^{+}} \Theta-\left(1-b^{+}-I T C-Z\right)}{(1-\tau)}
$$

Q-plus incorporates the same adjustments for tax-loss status as does Q-plus but now allows for leasing. The terms affected by a firm's taxable status are $B$, the present value of future depreciation deductions related to already owned capital, and $\tau$ in the denominator (which reflects the fact that the deductibility of adjustment costs is worth less to a tax exhausted firm). These values are assumed to equal zero for tax exhausted firms; TLCF does not appear because it is (by definition) equal to zero for taxable firms and (by assumption) equal to zero for tax exhausted firms. As in normal $Q_{1}$, leases are treated as debt, so $b$ continues to reflect the share of total capital -- either owned or leased -- financed with either conventional or lease debt. Although the ITC and $Z$ terms are lower for tax exhausted firms with respect to purchased assets, if such firms lease assets in perfectly competitive markets, then those terms equal the values relevant for a fully-taxable lessor.

$$
Q_{1} \text {-plus }=\frac{\frac{V-B^{*}-N}{K^{+}} \Theta-\left(1-b^{+}-I T C-Z\right)}{\left(1-\tau^{*}\right)}
$$

The final version of $Q$ continues the same leasing adjustments as in $Q_{l}$ and $Q_{1}$-plus but allows for transits between taxable and tax-loss status.

$$
\text { super } Q_{1} \text {-plus }=\frac{\frac{V-B^{* *}-N-T L C F^{* *}}{K^{+}} \Theta-\left(1-b^{+}-I T C-Z\right)}{\left(1-\tau^{* *}\right)}
$$

\subsection{Data Handling}

The analysis uses COMPUSTAT data from the "Full Coverage" files, including the 
research components. However, these data were supplemented with estimates of the value of the leased capital stock and the various tax parameters.

Regarding leases, the longest of which extend until the leased asset is almost worthless, close to the full value of the leased asset is amortized. The lessee essentially pays for the asset through the lease payments; because the leased asset is practically worthless when it reverts to the lessor, these "full payout" leases essentially transfer ownership to the lessee and are basically identical to an installment sale. This equivalence motivates the categorization of leases according to their perceived economic content so that similar transactions receive similar treatment. For tax purposes, "similar treatment" means that the depreciation deductions and ITC are passed to the lessee firm, just as would be the case if it were to purchase the asset. For financial reporting purposes, assets leased under "capital" leases are treated as if they were purchased with debt, so that assets and liabilities are entered on the firm's balance sheet.

On the other hand, leases that do not meet the criteria of these capital leases -"operating" leases for accounting purposes and true tax leases for tax purposes -receive different treatment that commands special recognition and data handling. True tax leases are the type that facilitate the tax benefit transfer and are therefore very important for this paper; because of the similarities between the tax and accounting categorizations of leases, "operating" leases are most likely to be these true leases. ${ }^{5}$ However, the accounting treatment of operating leases obscures the value of assets under such leases, because the data are presented as lease payments, not the value of leased goods, as is the case with investment financed by other means. In order to make these data comparable, the operating lease data must be capitalized to yield the values of the stock of assets under operating leases. O'Malley (1994a) presents a procedure for this conversion. Given

$5 \quad$ See Equipment Leasing Association (1990), p. 6. 
information about the type of equipment leased, typical lease terms, and other information needed to determine the amortization schedule of a lease, the algorithm determines the value of capital leased with operating leases that would generate the lease payments reported. Because operating and capital leases were not neatly differentiated in financial statements before a FASB rule that affected Q measures beginning in 1981, the data span 1981 - 1991.

The $Q$ specifications and the lease algorithm require estimates of various tax parameters that are not observed in financial reports that are used to construct COMPUSTAT data. Because the values of the ITC and depreciation deductions vary by asset and because this paper explains investment at the level of the firm, it is necessary to determine the distribution of investment by asset categories, find the ITC and $Z$ values for each asset category, and finally aggregate into firm-wide weighted averages. Further, the statutory values of these allowances vary across industries and years. To derive these tax terms, each firm is first classified into one of 61 industry groupings by primary SIC code. Then based on yearly industrylevel NIPA data on investment, firms' total levels of investment are distributed into 51 types of assets. Last, using data for ITC eligibility and tax depreciation compiled for Henderson and Liebman (1992), the NIPA asset categorizations are mapped into IRS categories so that the statutory ITC and depreciation deduction values may be determined that can then be factored according to the specification of $Q$.

\subsection{Econometrics}

Following Blundell et al. (1992), the specification of this paper reflects the possibility of two potential econometric concerns. The first potential problem is that the error term of any relevant regression may contain firm- and/or time-specific components; i.e.,

$$
\epsilon_{i t}=\eta_{i}+\phi_{t}+w_{i t}
$$


where $\eta_{i}$ is the firm fixed effect, $\phi_{t}$ is the time-specific effect, and $w_{i t}$ is assumed to be white noise. Obviously, if any of the variables of interest are correlated with a firm-specific term, then, without controlling separately for the fixed effect, these coefficients of interest would be biased. The fixed effects are eliminated by estimating the model in first-differences (which generates an MA(1) process among the $\mathrm{w}_{\mathrm{it}}$ ), while the time-specific effects are removed with dummy variables for each year in the panel.

The second econometric matter reflects the possibility that the regressors may be endogenous with respect to investment. As noted in Devereux (1989), the very issue addressed here is that past, current, and future investment affects the possibilities of tax exhaustion in any given period and therefore $Q$. This potential endogeneity suggests the use of an IV estimator; Blundell et al. (1992) motivate the use of the generalized method of moments (GMM) estimator outlined in Arellano and Bond (1991) that allows for endogeneity of regressors in a firstdifferenced equation. The essence of the model is that endogenous variables, dated $t$-h where $h \geq 2$, may be used as instruments in a differenced equation because they would not be correlated with the residuals that are MA(1); obviously, in addition to these instruments, exogenous regressors, as well as any other predetermined or exogenous variables, may also be used. A cost of estimator is that endogeneity of the regressors comes at the expense of assumptions on the time processes of the errors; nevertheless, the validity of these assumptions is testable with standard tests of overidentifying restrictions.

This estimator has the form:

$$
\hat{\beta}=\left(x^{\prime} Z A_{N} Z^{\prime} x\right)^{-1} x^{\prime} Z A_{N} Z^{\prime} y
$$

where $\mathrm{x}$ is the stacked vector of regressors, $\mathrm{y}$ is the stacked vector of $\Delta(\mathrm{I} / \mathrm{K})$, and $Z$ is the matrix of instruments, which (for firm $i$ ) has the form 


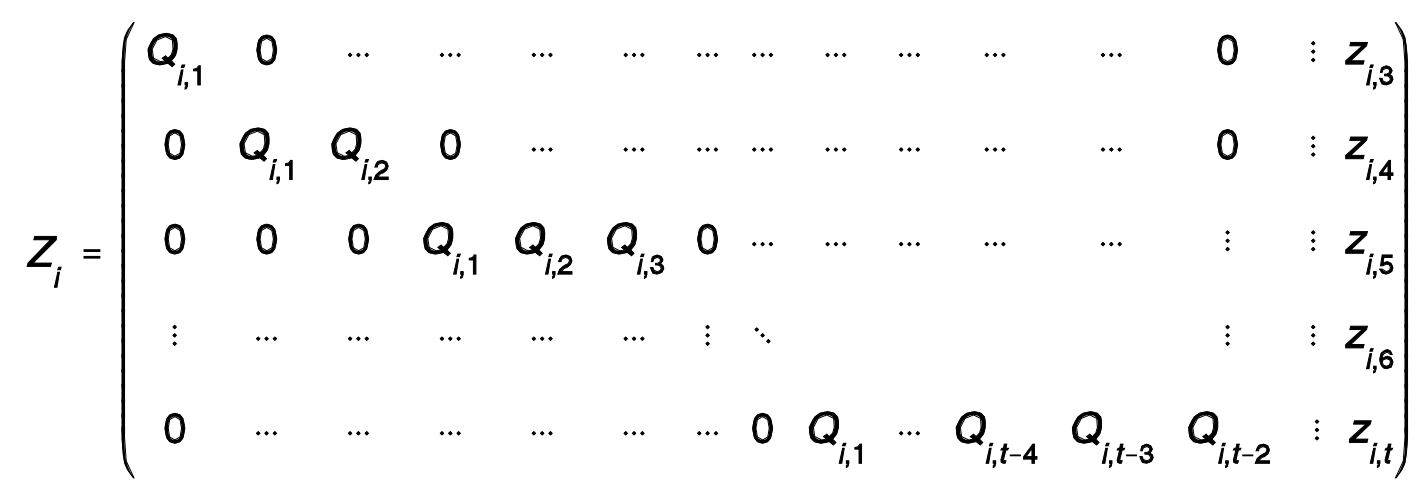

where $Q$, which may be endogenous, is used as an instrument. $z_{i}$ represents additional instruments.

$A_{N}$ is a weighting matrix for the event of general heteroscedasticity across both firms or time. As developed in White (1982), the optimal $A_{N}$ is:

$$
A_{N}=\left(\frac{1}{N} \sum_{i=1}^{N} Z_{i}^{\prime} \Delta \hat{v}_{i} \Delta \hat{v}_{i}^{\prime} Z_{i}\right)^{-1}
$$

where $\Delta v$ are consistent estimates of the first-differenced errors for each firm, obtained from an initial, consistent $\beta$ that uses

$$
A_{N}=\left(\frac{1}{N} \sum_{i=1}^{N} Z_{i}^{\prime} H Z_{i}^{\prime}\right)^{-1}
$$

where, given the MA(1) process for $\Delta \hat{v}_{\mathrm{it}}, \mathrm{H}$ is a matrix with twos on the leading diagonal, ones on each first off-diagonal, and zeros elsewhere, reflecting the $M A(1)$ process of the first-differenced residuals.

\section{$4 \quad$ Results}

Descriptive statistics of the $Q$ specifications are presented in Appendix $A$, and Appendix $B$ contains descriptive statistics for the other variables.

The most efficient estimator exploits all possible moment conditions; given the 
MA(1) process among the first-differenced residuals, this estimator uses the levels of the endogenous variables through period $t-2$. However, one-degree of freedom tests for second-order serial correlation produced test statistics that were frequently either within or near the boundaries of traditional confidence intervals. ${ }^{6}$ Similar tests for third-order serial correlation (produced with results with estimators that used endogenous variables lagged at least three periods as instruments) were always insignificant; therefore, all of the following results were computed with this more conservative set of instruments.

\subsection{Results for basic and augmented specifications}

Panel one of Table I presents results of the purest $Q$ specification, where $Q$ is a sufficient statistic for a firm's incentive to invest. To the extent that concern with previous results has centered on low Q coefficients (and therefore high implied marginal adjustment costs), the results show point estimates that increase as tax exhaustion is recognized for owned capital in columns one through three and then for all capital (i.e., including leased assets) in columns four through six. However, Wald tests reveal that $Q$-plus is not significantly different from Normal $Q$ and neither $Q_{1}$-plus nor Super $Q_{1}$-plus is significantly different from Normal $Q_{1}$; only Super Q-plus is significantly different from Normal Q. The point estimates in columns four through six are roughly twice as large as the analogous estimates that reflect only owned capital in columns one through three, and Wald tests confirm that these coefficients are significantly different from each other. Therefore, modifying $Q$ to reflect leasing does increase point estimates, implying lower adjustment costs, so that the tax-adjusted $Q$ model of investment can be improved with better recognition of leasing. For all specifications, Wald tests show that the time dummy variables are jointly statistically different from zero, and the $\mathrm{m}_{3}$ test statistics suggest that serial correlation is not a problem, so the instruments

$6 \quad$ See Arellano and Bond (1991). 
are assumably valid.

TABLE I

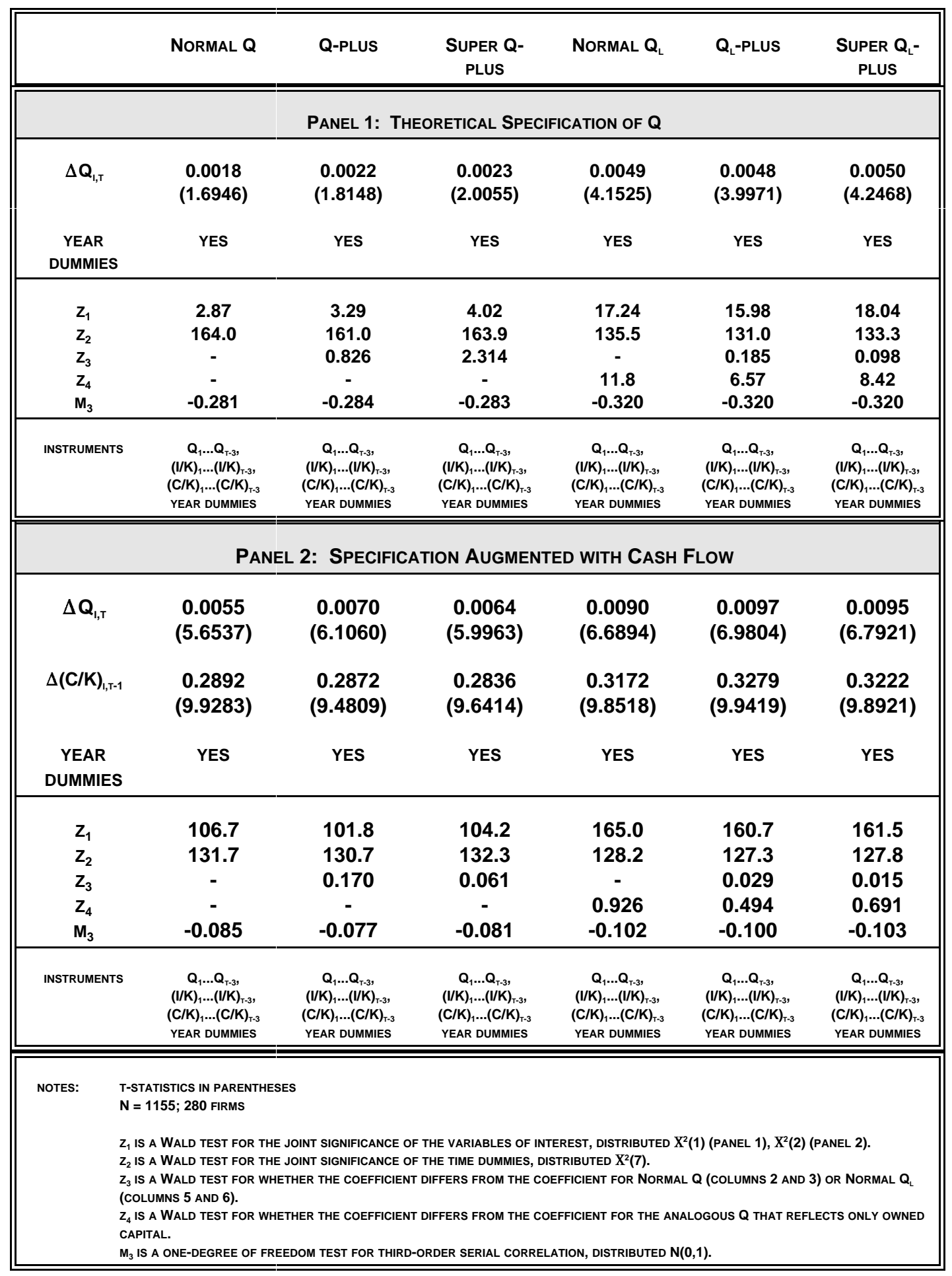


In the optimizing framework that motivates these equations, $Q$ alone is sufficient to explain investment; nevertheless, other variables have been shown to have considerable independent explanatory power. In particular, cash flow is frequently found to have high explanatory power, which has been interpreted to suggest that various capital market imperfections make internal finance cheaper than external funds so that the ability to generate internal funds facilitates investment. It may be that estimated cash flow coefficients are biased because of mismeasured $Q$ variables: a negative correlation between cash flow and the condition of tax exhaustion is plausible, so that the negative effect of tax exhaustion on investment is captured by cash flow variables, producing a positive coefficient. It is therefore possible that the improved specification employed here may "rescue" the $Q$ model so that cash flow is no longer significant. Panel two of Table I contains results of the original $Q$ specification, augmented by the firm's cash flow (scaled by the capital stock). ${ }^{7}$ The results show that after $Q$ is corrected for tax exhaustion and leasing, the cash flow effect does not disappear.

Inefficiency due to informational asymmetries obviously confounds the tractability of $Q$ models, because it contradicts the strong assumptions on stock market efficiency that are needed to make $Q$ an accurate indicator of the value of marginal investment. That there is little significant difference among the $Q$ specifications that control for tax exhaustion may imply inefficiency that weakens $Q$. Correlation coefficients of the various measures of $Q$ (presented in Table II) indicate that this outcome is a result of near-perfect correlation between the different versions of $Q$. These results mirror broadly those of Devereux, Keen, and Schiantarelli (1994), which finds similarly high correlations between alternative measures of $Q$ that control for tax nonlinearities but not leasing; that paper investigates further this relationship by regressing versions of $Q$ on each other and finds that "allowance

$7 \quad$ I enter the previous period's value because this value best represents internal capital that would be available for investment. 
for tax exhaustion (compared with assuming all firms to be fully tax paying) involves little more than subtracting a constant common across firms."

TABLE II

\begin{tabular}{|c|c|c|c|c|c|c|}
\hline \multicolumn{7}{|c|}{ Correlation Matrix of Alternate Measures of $Q$} \\
\hline NORMAL Q & 1 & & & & & \\
\hline Q-PLUS & 0.98 & 1 & & & & \\
\hline SUPER Q-PLUS & 0.95 & 0.984 & 1 & & & \\
\hline NORMAL $Q_{L}$ & 0.966 & 0.986 & 0.997 & 1 & & \\
\hline$Q_{L}-$ PLUS & 0.978 & 0.984 & 0.99 & 0.997 & 1 & \\
\hline SUPER $Q_{L}$-PLUU & 0.995 & 0.994 & 0.97 & 0.981 & 0.985 & 1 \\
\hline
\end{tabular}

\subsection{Results of an expanded specification}

Given that the deleterious effect of tax exhaustion on theoretical measures of investment incentives is shown easily and that incorporation of this scenario into the $Q$ framework should be straightforward, that $Q$ is nearly invariant to careful modelling of this scenario leads to some interesting implications. First is that tax exhaustion does not matter for a firm's overall health, so that market valuations are unaffected. For example, if leasing works to equilibrate cost of use differentials between firms, then (holding all else equal) tax exhaustion should not cause suboptimal investment decisions; otherwise, suboptimal investment should lower market valuations because capital stocks and the ability to generate dividends are reduced accordingly. Obviously, whether tax-exhausted firms invest less is testable; if tax-loss firms do actually invest suboptimally, then it would seem that information about tax exhaustion is not efficiently priced into market valuations. This consequence invalidates the efficient markets hypothesis needed to make $Q$ theory tractable empirically. 
One way to test whether tax exhaustion affects investment is to enter a firm's taxloss carryforwards as a separate regressor; a negative coefficient on the carryforward variable suggests reduced investment due to higher costs of capital. The carryforward term can be interacted with $Q$, and a negative sign suggests measurement error that is hypothesized to bias downwards the $Q$ coefficient in previous work.

Results for investment equations that include terms for tax-loss carryforwards and their interactions with $Q$ variables are presented in Table III. Panel one offers estimates without a cash flow term. The tax-loss coefficient seems large and is negative and very significant; moreover, the interaction term is also negative and quite precisely estimated. These results show that tax-loss status does affect adversely a firm's level of investment and that the coefficient for $Q$ is significantly lower for tax exhausted firms. Considering fully-taxable firms, the $Q$ coefficient is again significantly larger when explaining both owned and leased investment, buttressing the notion of measurement error among $Q$ specifications that ignore leasing. Panel two adds the cash flow term, which is again large, positive, and precisely estimated; the tax-loss carryforward variable and its interaction with $Q$ remain negative and statistically significant. Along with the results presented in Table I, these findings suggest that not controlling for tax exhaustion may not cause cash flow variables to enter with statistically significant, positive coefficients in other papers; indeed, in this specification with tax-loss carryforwards as a separate regressor, the effects of both variables are significant and precisely estimated. 


\section{TABLE III}

\begin{tabular}{|c|c|c|}
\hline & NORMAL Q & NORMAL $Q_{L}$ \\
\hline \multicolumn{3}{|c|}{ PANEL 1: Simple Q SPeCIFICATION WITH TLCF } \\
\hline$\Delta \mathbf{Q}_{1, \mathbf{T}}$ & $\begin{array}{c}0.0022 \\
(2.4056)\end{array}$ & $\begin{array}{c}0.0057 \\
(7.1106)\end{array}$ \\
\hline$\Delta \mathrm{TLCF}_{\mathrm{i}, \mathrm{T}-1}$ & $\begin{array}{c}-0.2376 \\
(-15.1930)\end{array}$ & $\begin{array}{c}-0.2294 \\
(-15.7696)\end{array}$ \\
\hline$\Delta\left(Q_{1, T}{ }^{*} T_{L C F} F_{1, T-1}\right)$ & $\begin{array}{c}-0.0187 \\
(-5.1031)\end{array}$ & $\begin{array}{c}-0.0503 \\
(-9.1804)\end{array}$ \\
\hline YEAR DUMMIES & YES & YES \\
\hline$z_{1}$ & 588.20 & 541.07 \\
\hline$z_{2}$ & 5458.0 & 15698.5 \\
\hline $\mathrm{z}_{4}$ & - & 6.63 \\
\hline$M_{3}$ & -0.230 & -0.222 \\
\hline INSTRUMENTS & $\begin{array}{c}\mathbf{Q}_{1} \ldots \mathbf{Q}_{\mathrm{T}-3} \\
(\mathrm{I} / \mathrm{K})_{1} \ldots(\mathrm{I} / \mathrm{K})_{\mathrm{T}-3} \\
(\mathrm{C} / \mathrm{K})_{1} \ldots(\mathrm{C} / \mathrm{K})_{\mathrm{T}-3} \\
\text { TLCF }_{1} \ldots \mathrm{TLCF}_{\mathrm{T}-3} \\
\text { YEAR DUMMIES }\end{array}$ & $\begin{array}{c}\mathbf{Q}_{1} \ldots \mathbf{Q}_{\mathrm{T}-3}, \\
(\mathrm{I} / \mathrm{K})_{1} \ldots(\mathrm{I} / \mathrm{K})_{\mathrm{T}-3}, \\
(\mathrm{C} / \mathrm{K})_{1} \ldots(\mathrm{C} / \mathrm{K})_{\mathrm{T}-3}, \\
\text { TLCF }_{1} \ldots \mathrm{TLCF}_{\mathrm{T}-3}, \\
\text { YEAR DUMMIES }\end{array}$ \\
\hline \multicolumn{3}{|c|}{ PANel 2: Simple Q Specification tLCF and CASH Flow } \\
\hline$\Delta \mathbf{Q}_{\mathrm{l}, \mathrm{T}}$ & $\begin{array}{c}0.0067 \\
(9.8692)\end{array}$ & $\begin{array}{c}0.0118 \\
(16.8017)\end{array}$ \\
\hline$\Delta(\mathrm{C} / \mathrm{K})_{1, \mathrm{~T}-1}$ & $\begin{array}{c}0.2791 \\
(18.6264)\end{array}$ & $\begin{array}{c}0.3739 \\
(23.4829)\end{array}$ \\
\hline$\Delta \mathrm{TLCF}_{\mathrm{l}, \mathrm{T}-1}$ & $\begin{array}{c}-0.1708 \\
(-9.5710)\end{array}$ & $\begin{array}{c}-0.1925 \\
(-13.5431)\end{array}$ \\
\hline$\Delta\left(Q_{1, T}^{*} T_{L C F} F_{1, T-1}\right)$ & $\begin{array}{c}-0.0336 \\
(-9.6187)\end{array}$ & $\begin{array}{c}-0.0709 \\
(-13.8190)\end{array}$ \\
\hline YEAR DUMMIES & YES & YES \\
\hline$z_{1}$ & 1301.42 & 1041.80 \\
\hline $\mathrm{z}_{2}$ & 1618.76 & 1773.01 \\
\hline $\mathrm{z}_{4}$ & - & 1.82 \\
\hline $\mathbf{M}_{3}$ & -0.018 & 0.033 \\
\hline INSTRUMENTS & $\begin{array}{c}\mathbf{Q}_{1} \ldots \mathrm{Q}_{\mathrm{T}-3} \\
(\mathrm{I} / \mathrm{K})_{1} \ldots(\mathrm{I} / \mathrm{K})_{\mathrm{T}-3} \\
(\mathrm{C} / \mathrm{K})_{1} \ldots(\mathrm{C} / \mathrm{K})_{\mathrm{T}-3} \\
\text { TLCF }_{1} \ldots \mathrm{TLCF}_{\mathrm{T}-3}, \\
\text { YEAR DUMMIES }\end{array}$ & $\begin{array}{c}\mathbf{Q}_{1} \ldots \mathrm{Q}_{\mathrm{T}-3}, \\
(\mathrm{I} / \mathrm{K})_{1} \ldots(\mathrm{I} / \mathrm{K})_{\mathrm{T}-3}, \\
(\mathrm{C} / \mathrm{K})_{1} \ldots(\mathrm{C} / \mathrm{K})_{\mathrm{T}-3}, \\
\text { TLCF }_{1} \ldots \mathrm{TLCF}_{\mathrm{T}-3}, \\
\text { YEAR DUMMIES }\end{array}$ \\
\hline AS & & \\
\hline
\end{tabular}

Viewed in light of the results in Table I, the results for the specification in Table 
III seem to suggest problems for the empirical performance of the $Q$ methodology even after controlling carefully for taxes and leasing. Table III suggests that tax exhaustion does have a significantly negative effect on investment decisions, yet this conclusion is not nearly so clear when comparing columns in Table I, where tax exhaustion is not and then is built into the $Q$ variable. The strong results in Table III imply that the effects of tax exhaustion are overwhelmed in the $Q$ framework in Table I. If this result obtains because market valuations do not incorporate efficiently information about taxation and/or leasing, then a major assumption of the $Q$ framework is violated.

Beyond the conclusion that investment is reduced by tax exhaustion and that $Q$ may be flawed because it is insensitive to this effect, an interesting result of Table III is that the lease market appears somewhat inefficient because the effects of tax exhaustion on investment remain for the regressions that explain leased as well as owned investment. Although O'Malley (1994a) finds that tax exhausted firms are more likely to lease, presumably to reduce the costs of tax exhaustion, these results suggest that the structure and performance of the leasing market is an important topic for future research.

\section{Conclusions}

The Introduction promised that this paper would address whether tax-loss carryforwards affect investment and, in doing so, whether the empirical performance of $Q$ models suffers because of omission of the effects of tax asymmetries and leasing that may be a response to tax exhaustion. Theory, previous empirical models of investment incentives, and now the results in Table III combine to confirm that tax exhaustion reduces investment. The two primary charges against previous $Q$ results are that they are too low and that cash flow variables have large, positive coefficients, while theory suggests that $Q$ alone 
should explain investment. One possibility is that $Q$ is mismeasured, with the implication that $Q$ coefficients would be biased downward and creating the possibility for cash flow to have significant explanatory power. In addition to the clear effects of tax-loss carryforwards when they are entered as a separate regressor, when they are interacted with $Q$, a negative coefficient on the interaction term obtains, so it seems that $Q$ coefficients should increase when they reflect the possibility of tax exhaustion. Nevertheless, careful modelling of tax exhaustion within the $Q$ framework yields results that are statistically invariant to such careful controls. Moreover, when adjustments are made for tax exhaustion and leasing, the cash flow coefficient remains significantly positive and relatively large. While the inclusion of leasing in the model does increase $Q$ coefficients, suggesting some amelioration of measurement error and the implication of very high adjustment costs, the gain is not large in an absolute sense so that the coefficients -- and the implied adjustment costs -- remain within the range of earlier results.

Rejecting the $Q$ model and/or efficient markets hypotheses remains hasty. Promising lines of research include learning more about the actual cost of spells of tax exhaustion in addition to how information on such tax disadvantage is disseminated and priced (or not priced) into equity markets. Finally, a related, promising issue concerns the efficiency of the leasing market and the extent to which leasing can ameliorate the disadvantages of tax-loss status. 


\section{REFERENCES}

Altshuler, Rosanne and Alan J. Auerbach, 1990. "The Significance of Tax Law Asymmetries: An Empirical Investigation," Quarterly Journal of Economics 105(1):61-86.

Arellano, Manuel and Stephen Bond, 1991. "Some Tests of Specification for Panel Data: Monte Carlo Evidence and an Application to Employment Equations," Review of Economic Studies 58(2):277-97.

Auerbach, Alan J., 1983. "Corporate Taxation in the U.S.," Brookings Papers on Economic Activity 1983(2):451-513.

Auerbach, Alan J., 1986. "The Dynamic Effects of Tax Law Asymmetries," Review of Economic Studies 53:205-225.

Auerbach, Alan J. and James M. Poterba, 1987. "Tax-Loss Carryforwards and Corporate Tax Incentives," in Martin Feldstein, ed., The Effects of Taxation on Capital Accumulation. Chicago and London: University of Chicago Press, pp. 305-38.

Blundell, Richard, Michael P. Devereux, and Fabio Schiantarelli, 1992. "Investment and Tobin's Q," Journal of Econometrics 51(1-2):233-57.

Chirinko, Robert S., 1987. "Tobin's Q and Financial Policy," Journal of Monetary Economics 19(1):69-87.

Cordes, Joseph J. and Steven M. Sheffrin, 1983. "Estimating the Tax Advantage of Corporate Debt," Journal of Finance 38(1):95-105.

Devereux, Michael P., 1989. "Tax Asymmetries, the Cost of Capital and Investment: Some Evidence from United Kingdom Panel Data," Economic Journal 99(395):103-12 (Supplement 1989).

Devereux, Michael, Michael J. Keen, and Fabio Schiantarelli, 1991. "Corporation Tax Asymmetries and Investment: Evidence from UK Panel Data," Journal of Public Economics 53(3):395-418.

Edwards, J. S. S. and M. J. Keen, 1985. "Taxes Investment and Q," Review of Economic Studies 52(4):665-679.

Edwards, J. S. S. and C. P. Mayer, 1991. "Leasing, Taxes, and the Cost of Capital," Journal of Public Economics 44:173-197. 
Equipment Leasing Association, 1992, 1991, 1990, 1989, 1988, 1987, 1986, 1987, 1985, 1984, 1983. Survey of Industry Activity.

Hall, Robert E. and Dale W. Jorgenson, 1967. "Tax Policy and Investment Behavior," American Economic Review 57:391-414.

Hayashi, Fumio, 1982. "Tobin's Marginal q and Average q: A Neoclassical Interpretation," Econometrica 50(1):213-24.

Hayashi, Fumio, 1985. "Corporate Finance Side of the Q Theory of Investment," Journal of Public Economics 27(3):261-80.

Hayashi, Fumio and Tohru Inoue, 1991. "The Relation between Firm Growth and Q with Multiple Capital Goods: Theory and Evidence from Panel Data on Japanese Firms," Econometrica 59(3):731-53.

Henderson, Yolanda K. and Jeffrey B. Liebman, 1992. "Capital Costs, Industrial Mix, and the Composition of Business Investment," New England Economic Review January/February 1992:67-92.

Mayer, Colin P., 1986. "Corporation Tax, Finance, and the Cost of Capital," Review of Economic Studies 53:93-112.

O'Malley, Michael P., 1994a. "The Effects of Taxes on Leasing Decisions: Evidence from Panel Data," mimeo.

O'Malley, Michael P., 1994b. "Simulating the Effect of the AMT on Leasing Decisions: Fewer Gains than Expected?" mimeo.

Poterba, James M. and Lawrence H. Summers, 1983. "Dividend Taxes, Corporate Investment, and Q," Journal of Public Economics 22(2):135-67.

Schiantarelli, Fabio and D. Georgoutsos, 1990. "Imperfect Competition, Tobin's q and Investment: Evidence from Aggregate UK Data," European Economic Review 34:1061-78.

Summers, Lawrence H., 1981. "Taxation and Corporate Investment: A q-Theory Approach," Brookings Papers on Economic Activity 0(1):67-127.

Tobin, James, 1969. "A General Equilibrium Approach to Monetary Theory," Journal of Money, Credit, and Banking 1:15-29.

White, Halbert, 1982. "Instrumental Variables Regression with Independent Observations," Econometrica 50(2):483-99. 
Appendix A

\begin{tabular}{|c|c|c|c|c|c|c|}
\hline & \multicolumn{6}{|c|}{ Descriptive Statistics for Q Specifications, 1982 - 1991} \\
\hline & & mean & standard deviation & minimum & maximum & number \\
\hline \multirow{6}{*}{1982} & Normal Q & 0.1887 & 1.6313 & -1.8989 & 9.0667 & 199 \\
\hline & Q-plus & 0.1225 & 1.4691 & -1.8989 & 9.0667 & 199 \\
\hline & Super Q-plus & 0.1763 & 1.4091 & -1.8989 & 8.9049 & 199 \\
\hline & $Q_{1}$ & 0.1748 & 1.4486 & -1.8544 & 8.7407 & 199 \\
\hline & $Q_{1}$-plus & 0.2032 & 1.5438 & -1.8989 & 8.9049 & 199 \\
\hline & Super $Q_{1}$-plus & 0.1049 & 1.5211 & -2.3067 & 8.8635 & 199 \\
\hline \multirow[t]{6}{*}{1983} & Normal Q & 0.7248 & 2.0766 & -5.2418 & 11.6202 & 220 \\
\hline & Q-plus & 0.6508 & 1.9031 & -5.2418 & 8.4525 & 220 \\
\hline & Super Q-plus & 0.6409 & 1.7417 & -5.2418 & 7.8235 & 220 \\
\hline & $Q_{1}$ & 0.6418 & 1.7614 & -5.1247 & 7.6845 & 220 \\
\hline & $Q_{1}$-plus & 0.6665 & 1.857 & -5.2418 & 8.1467 & 220 \\
\hline & Super $Q_{-}$-plus & 0.6416 & 1.9429 & -5.1599 & 8.6081 & 220 \\
\hline \multirow[t]{6}{*}{1984} & Normal Q & 1.3421 & 2.5137 & -1.4306 & 14.6499 & 229 \\
\hline & Q-plus & 1.2244 & 2.3209 & -1.4306 & 13.341 & 229 \\
\hline & Super Q-plus & 1.1859 & 2.1257 & -1.4306 & 13.341 & 229 \\
\hline & $Q_{1}$ & 1.186 & 2.1377 & -1.397 & 13.0896 & 229 \\
\hline & $Q_{i}$-plus & 1.2392 & 2.2328 & -1.4306 & 13.341 & 229 \\
\hline & Super $Q_{-}$-plus & 1.2236 & 2.3647 & -1.4357 & 13.0541 & 229 \\
\hline \multirow[t]{6}{*}{1985} & Normal Q & 0.8776 & 2.0673 & -8.9236 & 12.4022 & 243 \\
\hline & Q-plus & 0.796 & 1.9544 & -8.9236 & 10.6486 & 243 \\
\hline & Super Q-plus & 0.8173 & 1.8189 & -8.9236 & 10.6486 & 243 \\
\hline & $Q_{1}$ & 0.7968 & 1.8188 & -8.7374 & 10.4514 & 243 \\
\hline & $Q_{i}$-plus & 0.8266 & 1.8788 & -8.9236 & 10.6486 & 243 \\
\hline & Super $Q_{-}$-plus & 0.782 & 1.9707 & -8.772 & 10.4126 & 243 \\
\hline \multirow[t]{6}{*}{1986} & Normal Q & 1.3143 & 2.1348 & -7.2381 & 9.3259 & 224 \\
\hline & Q-plus & 1.2263 & 2.09 & -7.2381 & 9.3259 & 224 \\
\hline & Super Q-plus & 1.1995 & 1.9401 & -7.2381 & 9.2248 & 224 \\
\hline & $Q_{1}$ & 1.176 & 1.9334 & -7.0844 & 9.0606 & 224 \\
\hline & $Q_{i}$-plus & 1.2234 & 1.9831 & -7.2381 & 9.2248 & 224 \\
\hline & Super $Q_{-}$-plus & 1.2138 & 2.0759 & -7.1137 & 9.1285 & 224 \\
\hline \multirow[t]{6}{*}{1987} & Normal Q & 1.7701 & 3.1342 & -1.3 & 29.1832 & 204 \\
\hline & Q-plus & 1.6623 & 2.6887 & -1.3 & 17.3618 & 204 \\
\hline & Super Q-plus & 1.5756 & 2.3898 & -1.3 & 9.9892 & 204 \\
\hline & $Q_{1}$ & 1.5692 & 2.4426 & -1.2735 & 13.0235 & 204 \\
\hline & $Q_{1}$-plus & 1.6227 & 2.574 & -1.3 & 16.4897 & 204 \\
\hline & Super $Q_{-}$-plus & 1.669 & 2.8514 & -1.2952 & 22.9161 & 204 \\
\hline \multirow[t]{6}{*}{1988} & Normal Q & 1.6665 & 3.676 & -1.4635 & 28.335 & 193 \\
\hline & Q-plus & 1.5855 & 3.3648 & -1.4635 & 28.1519 & 193 \\
\hline & Super Q-plus & 1.4887 & 3.0471 & -1.4635 & 27.3908 & 193 \\
\hline & $Q_{1}$ & 1.4774 & 3.0601 & -1.4423 & 27.0733 & 193 \\
\hline & $Q_{\uparrow}$-plus & 1.5159 & 3.1526 & -1.4635 & 27.3908 & 193 \\
\hline & Super $Q_{-}$-plus & 1.5893 & 3.4636 & -1.4583 & 27.8099 & 193 \\
\hline \multirow[t]{6}{*}{1989} & Normal Q & 1.6662 & 2.8812 & -1.1026 & 19.5431 & 178 \\
\hline & Q-plus & 1.5986 & 2.7412 & -1.1026 & 19.5431 & 178 \\
\hline & Super Q-plus & 1.519 & 2.5709 & -0.9799 & 19.0745 & 178 \\
\hline & $Q_{1}$ & 1.503 & 2.5773 & -1.0628 & 18.8547 & 178 \\
\hline & $Q_{1}$-plus & 1.5439 & 2.6362 & -0.9799 & 19.0745 & 178 \\
\hline & Super $Q_{-1}$ plus & 1.5912 & 2.7739 & -1.1304 & 19.3037 & 178 \\
\hline \multirow[t]{6}{*}{1990} & Normal Q & 1.8292 & 2.7073 & -2.5779 & 13.185 & 165 \\
\hline & Q-plus & 1.7538 & 2.6474 & -2.5779 & 13.185 & 165 \\
\hline & Super Q-plus & 1.6589 & 2.414 & -2.328 & 10.5042 & 165 \\
\hline & $Q_{1}$ & 1.6375 & 2.4186 & -2.294 & 10.3829 & 165 \\
\hline & $Q_{-}$-plus & 1.6827 & 2.4644 & -2.328 & 10.5042 & 165 \\
\hline & Super $Q_{-}$-plus & 1.7487 & 2.6465 & -2.5549 & 13.0176 & 165 \\
\hline \multirow[t]{6}{*}{1991} & Normal Q & 1.6699 & 3.0215 & -1.9577 & 14.1905 & 140 \\
\hline & Q-plus & 1.6364 & 3.0099 & -1.9577 & 14.1905 & 140 \\
\hline & Super Q-plus & 1.5559 & 2.7456 & -1.9577 & 12.0191 & 140 \\
\hline & $Q_{1}$ & 1.521 & 2.7357 & -1.9284 & 11.881 & 140 \\
\hline & $Q_{1}$-plus & 1.5515 & 2.769 & -1.9577 & 12.0191 & 140 \\
\hline & Super $Q_{-}$-plus & 1.6096 & 2.9869 & -1.9435 & 14.0111 & 140 \\
\hline
\end{tabular}


Appendix B

Descriptive Statistics for All Firms and the Tax-Loss Subsample

all firms tax-loss firms tax-loss share

1982

number

199

15

0.075

total investment

34658.7

owned investment

31635.2

total capital

208245.6

owned capital

196459.3

mean $(\mathrm{I} / \mathrm{K})_{\text {total }}$

0.164

0.152

0.267

mean $(\mathrm{C} / \mathrm{K})$

0.175

0.105

1733.7

1400.7

0.050

9741.6

0.044

8964.3

0.047

0.220

0.046

mean super Q-plus

mean super $Q_{\text {-1 }}$-plus

mean TLCF/Sales

0.165

0.200

0.458

0.322

0.069

1983

number

220

20

0.091

total investment

26857.0

2080.8

1733.9

0.077

owned investment

23183.6

total capital

228684.6

owned capital

215085.7

12367.2

0.075

0.054

0.163

11317.1

0.053

mean $(\mathrm{I} / \mathrm{K})_{\text {total }}$

mean $(\mathrm{I} / \mathrm{K})_{\text {owned }}$

0.148

0.180

mean $(\mathrm{C} / \mathrm{K})$

0.241

0.159

0.128

0.642

0.844

0.642

0.879

0.102

mean super $Q_{1}$-plus
mean TLCF/Sales

1984

number

229

22

0.096

total investment

35644.7

31700.8

owned investment

236187.9

total capital

220138.1

0.196

mean $(\mathrm{I} / \mathrm{K})_{\text {total }}$

0.183

0.249

1.186

3140.0

0.088

2728.3

0.086

14313.0

0.061

13037.2

0.059

mean $(I / K)_{\text {owned }}$

0.246

0.236

0.125

mean super Q-plus

1.224

1.013

1.154

0.121 
1985

number

243

28

0.115

total investment

42222.9

4031.1

0.095

owned investment

36736.1

3446.1

0.094

255066.9

21224.9

0.083

owned capital

236750.7

19678.8

0.083

mean $(\mathrm{I} / \mathrm{K})_{\text {total }}$

0.231

0.193

0.216

0.183

0.278

0.797

0.182

0.311

0.782

0.290

0.149

mean TLCF/Sales

1986

number

224

33

0.147

total investment

48454.1

4848.1

0.100

42429.0

4092.3

0.096

297897.3

33570.8

0.113

total capital

278011.1

30746.6

0.111

mean $(\mathrm{I} / \mathrm{K})_{\text {total }}$

mean $(\mathrm{I} / \mathrm{K})_{\text {owned }}$

0.218

0.169

0.206

0.152

0.268

0.145

1.176

0.223

mean super Q-plus

1.214

0.158

0.170

mean TLCF/Sales

1987

number

204

26

0.127

total investment

43598.2

3607.1

3155.5

0.083

38129.6

total capital

307913.7

26045.5

0.083

286169.4

23486.2

0.085

0.215

0.147

mean $(\mathrm{l} / \mathrm{K})_{\text {total }}$

0.202

0.139

mean $(\mathrm{C} / \mathrm{K})$

0.266

0.153

1.569

0.987

1.272

mean super $Q_{\text {-plus }}$

1.669

0.099 
1988

number

193

25

0.130

total investment

51386.1

owned investment

45845.0

total capital

307830.7

owned capital

284760.0

0.206

mean $(\mathrm{I} / \mathrm{K})_{\text {total }}$

0.197

0.276

mean $(\mathrm{C} / \mathrm{K})$

mean super $Q$-plus

mean super $Q_{\text {-1 }}$-plus

1.477

1.589

5396.2

0.105

4924.6

0.107

28879.4

0.094

26174.1

0.092

mean TLCF/Sales

0.228

0.220

0.199

0.882

1.238

0.075

1989

number

178

26

0.146

total investment

53943.7

48773.2

owned investment

315053.7

owned capita

291347.6

mean $(\mathrm{I} / \mathrm{K})_{\text {total }}$

mean $(\mathrm{I} / \mathrm{K})_{\text {owned }}$

mean $(\mathrm{C} / \mathrm{K})$

mean super Q-plus

mean super $Q_{1}$-plus

mean TLCF/Sales

0.206

0.200

0.309

1.503

1.591

6680.9

0.124

6136.4

0.126

32513.5

0.103

29458.2

0.101

1990

number

165

24

0.145

total investment

59213.7

0.193

0.191

0.231

0.515

0.665

0.076

53554.3

owned investment

326784.0

owned capital

300803.5

0.191

0.185

0.315

1.637

7714.3

0.130

7062.6

0.132

34986.7

0.107

32268.3

0.107

mean $(\mathrm{I} / \mathrm{K})_{\text {total }}$

mean $(\mathrm{I} / \mathrm{K})_{\text {owned }}$

0.183

0.174

0.210

mean super Q-plus

mean super $Q_{1}$-plus

1.749

0.552

0.610

0.096 
1991

number

140

22

0.157

total investment

43921.8

8332.5

7995.1

0.190

owned investment

39442.7

total capital

290348.8

owned capital

mean $(\mathrm{I} / \mathrm{K})_{\text {total }}$

265579.5

mean $(\mathrm{I} / \mathrm{K})_{\text {owned }}$

0.147

45595.0

0.203

0.157

43611.9

0.164

mean $(\mathrm{C} / \mathrm{K})$

0.140

0.142

0.134

0.291

1.521

1.610

0.225

0.061

$-0.003$

mean super $Q_{-}$-plus

mean TLCF/Sales

0.084 